\title{
An Economic Evaluation of the Loye Quarry of Atiwa Quarries Limited*
}

\author{
${ }^{1}$ D. Mireku-Gyimah and ${ }^{2}$ N. K. Owusu Ansah \\ ${ }^{1}$ University of Mines and Technology, Tarkwa, PO Box 238, Tarkwa \\ ${ }^{2}$ Tristen Consult Limited, PO Box 9946, KIA, Accra
}

Mireku-Gyimah, D. and Owusu Ansah, N. K. (2017), “An Economic Evaluation of the Loye Quarry of Atiwa Quarries Limited”, Ghana Mining Journal, Vol. 17, No. 1, pp. 43 - 53.

\begin{abstract}
Atiwa Quarries Limited (AQL) is one of the large operating granite quarries in the Central Region of Ghana. AQL's current production of $24000 \mathrm{~m}^{3}$ of aggregates per month cannot meet current demand let alone support a new contract to supply 25 $000 \mathrm{~m}^{3}$ of aggregates per month for a major road infrastructure project. Fortunately, AQL has another granite concession at Loye, about $3 \mathrm{~km}$ from the first concession, with estimated granite reserves of $6286208 \mathrm{~m}^{3}$, which can be developed as a new quarry to meet the demand of the new contract. This will require capital to build infrastructure, purchase equipment, recruit labour and provide working capital. The objective of this paper is to evaluate the economic viability of the new quarry, considering it as a stand-alone project. The yearly revenue was estimated based on projected production of 25000 $\mathrm{m}^{3} /$ month and average price of US\$ $15.63 / \mathrm{m}^{3}$. Capital and operating costs were estimated using detailed cost estimation method based on quotations from equipment suppliers and operational unit costs of AQL. It turns out that AQL can generate yearly gross revenue of US 4.69 million but requires total capital of US\$ 3.67 million; the yearly operating cost is US\$1.72 million. Cash flow and sensitivity analyses using Net Present Value (NPV) and Internal Rate of Return (IRR) as criteria, and risk analysis using Monte Carlo simulation method were carried out. The economic analysis indicates that based on AQL's preferred capital structure of $80 \%$ equity and $20 \%$ loan, the NPV is $\$ 5.17$ million and the IRR is $53.01 \%$, showing the new quarry is profitable; the sensitivity analysis indicates that the project can withstand up to $40 \%$ drop in revenue, or over $60 \%$ increase in capital or operating cost. The risk profile indicates a probability of success of $98.2 \%$. The study therefore recommends that AQL invests in the new quarry as it is economically viable.
\end{abstract}

Keywords: Granite Quarry, Net Present Value, Internal Rate of Return, Sensitivity Analysis, Risk Analysis

\section{Introduction}

Atiwa Quarries Limited (AQL) is one of the large operating quarries in the Awutu-Senya Municipality in the Central Region of Ghana. It is located off the main Accra-Winneba road, some $20 \mathrm{~km}$ from Accra, the national capital and is a major source of aggregates for the Greater Accra Region. Although AQL is producing an average of 24000 $\mathrm{m}^{3}$ of aggregates per month from its operation, it is unable to meet the huge demand for its products.

Against the background of its inability to meet current demand, AQL has recently received a new contract to supply $25000 \mathrm{~m}^{3}$ of aggregates per month for a major road infrastructure project which cannot be met with current production level. Fortunately, AQL has another granite concession at Loye which is about $3 \mathrm{~km}$ from its current concession (see Fig. 1). The vegetation here is made up of semi-deciduous forest and coastal savannah grassland. The area experiences a fivemonth dry season starting from November to March during which period the dry North-East Trade Winds blow across the area. The dry season is followed by a seven-month rainy season which starts from April to October during which the moist South-West Monsoon blows across the area. The mean annual rainfall of the area is about $750 \mathrm{~mm}$.
Temperatures are high throughout the year and range from $23{ }^{\circ} \mathrm{C}$ to $28^{\circ} \mathrm{C}$ (Anon., 2013).

The area is basically low-lying and is underlain by Birrimian rocks, which consist of granites and phyllites with limited overburden material of lateritic soil of thickness ranging from $0.6 \mathrm{~m}$ to 3 $\mathrm{m}$. There are protruding granitic rocks in some areas (Kesse, 1985). The granite has a thickness of more than $40 \mathrm{~m}$, although the quarry depth is planned to be $30 \mathrm{~m}$ in the short and medium terms.

The Loye concession has a total area of 17.44 ha and estimated Granite Reserves (GR) of 6286208 $\mathrm{m}^{3}$, which can be developed as a new quarry to meet the demand of the contract and to supplement current production after the contract has expired. This will require some capital to put up infrastructure and purchase equipment. AQL will also require working capital and additional labour.

A major concern of AQL's Board of Directors (BoD) is to assess the economic viability of the new quarry as a stand-alone project, under the same BoD. This paper undertook the economic analysis of AQL's proposed new quarry to provide the basis for the BoD's decision to undertake the project or otherwise. 


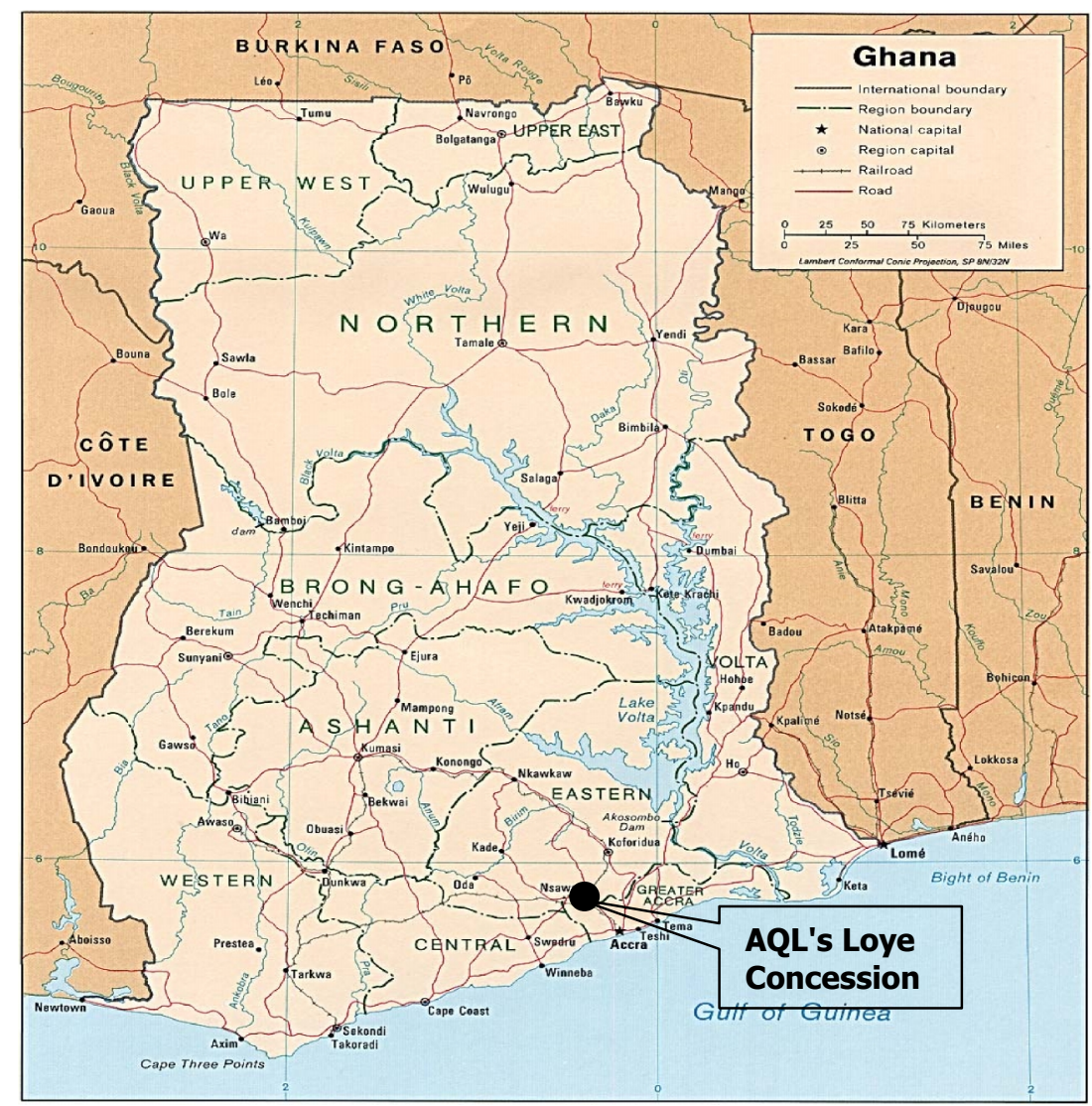

Fig. 1 Location of Loye Concession of Atiwa Quarries Limited

\section{Resources and Methods Used}

\subsection{Materials}

Data from AQL consisting of granite reserves, projected production level, selling price of aggregates, unit cost figures, preferred capital structure as well as relevant data from operating quarries within the Awutu-Senya Municipality were used in this study.

\subsection{Methods}

\subsubsection{Revenue Estimate}

Granite aggregates of various sizes will be produced. Each size would sell at a different price and the quantity of each size to be produced and sold every month would be different depending on the demand. For the purpose of this evaluation, the Weighted Average Price (WAP), estimated to be \$ $15.63 / \mathrm{m}^{3}$, is used to project the Monthly Revenue (MR) based on the planned Monthly Production (MP) of $25000 \mathrm{~m}^{3}$ of granite aggregates as:

$$
\mathrm{MR}=\mathrm{MP} \times \mathrm{WAP}
$$

Thus, the Annual Gross Revenue (AGR) is:

$$
\mathrm{AGR}=12 \mathrm{MR}=12 \mathrm{MP} \times \mathrm{WAR}
$$

\subsubsection{Capital Cost Estimate}

In estimating the capital cost, it is assumed that basic mining equipment are exempted from import duties as outlined in the minerals laws of Ghana (Anon., 2006; Anon., 2015). All cost estimates are made in US dollars; local cost components have been converted from Ghana cedis to US dollars using an exchange rate of US\$ $1.00=\mathrm{GH} \varnothing 4.00$. The capital cost estimates are based on price quotations of equipment from supply agencies in Ghana and overseas.

The capital costs are grouped into categories with the following code numbers:

(i) (CC1) Pre-production Cost;

(ii) (CC2) Direct Capital Cost;

(iii) (CC3) Indirect Capital Cost; and

(iv) (CC4) Allowances.

Pre-production costs are quoted from expenses to date of AQL and include exploration, acquisition and consultancy costs. 


\subsubsection{Operating Cost Estimate}

In the estimation of operating cost, it is assumed that both skilled and unskilled labour are readily available in Ghana. Therefore local labour will be used for the project; where necessary, training will be given to suitable candidates for various tasks.

The operating cost estimates for drilling and blasting; mucking; hauling; road maintenance; crushing and screening; re-handling and loading; and supervision and labour are gathered from AQL's current operation and from quarries operating under similar conditions within the Awutu-Senya Municipality. The remuneration for employees is based on current rates used for all categories of workers in the granite quarry industry. Estimates are based on a work schedule of 1 shift of 8 hours per day for a total of 300 working days a year and planned aggregate production of $300000.00 \mathrm{~m}^{3}$ per year. Boulders are to be hauled over an average distance of $500 \mathrm{~m}$ to the crusher and overburden is to be hauled over an average distance of $1 \mathrm{~km}$ to the overburden stockpile for use in future land reclamation. In order to take care of uncertainties in the determination of operating cost components and unexpected challenges associated with operating conditions, an operating cost contingency allowance of $12 \%$ is provided.

\subsubsection{Working Capital Estimate}

Working Capital (WC) for the new quarry is determined as a portion of the Annual Operating Cost (AOC):

$$
\mathrm{WC}=\mathrm{AOC} \times \frac{\mathrm{Y} \text { months }}{12 \text { months }}
$$

The value of $\mathrm{Y}$ depends on the length of time it takes the quarry products to reach the market and for payment to be received by the quarry. For quarries, a period of three months is deemed appropriate.

\subsubsection{Investment Decision Criteria}

If the goal of management is to create real value for shareholders, then it is necessary to make decisions based on a measured value to distinguish between acceptable projects in a consistent manner (Scholleová et al., 2010). Any successful investment decision method must respect the following two basic principles (Gentry and O'Neil, 1984):

(i) Bigger benefits are preferable to smaller benefits; and

(ii) Early benefits are preferable to later benefits.
There are numerous measures of the economic attractiveness of capital projects. They are broadly divided into accounting measures such as return on investment and discounted cash flow measures such as net present value. The difference between the two is that the discounted cash flow measures take into account the time value of money, whereas the other does not. For major capital projects like mineral projects that are expected to last a number of years, discounted cash flow technique is preferred. In this paper, the two most popular of the discounted cash flow criteria, the Net Present Value (NPV) and the Internal Rate of Return (IRR), are used.

\section{Net Present Value (NPV)}

The NPV is defined as the difference between the present value of all cash inflows and the sum of the present value of all cash outflows calculated at the required rate of return. It may be expressed mathematically as (Mireku-Gyimah, 2016):

$\mathrm{NPV}=\Sigma \mathrm{PV}$ of Cash Inflows@ $\mathrm{i}^{*}-\Sigma \mathrm{PV}$ of Cash Outflows@i*

If a project's NPV is positive (NPV $>0$ ), the project is considered to be economically acceptable. When the NPV is zero (NPV $=0)$, the project breaks even. When the NPV is negative $(\mathrm{NPV}<0)$, the project is considered to be economically unacceptable.

\section{Internal Rate of Return (IRR)}

The Internal Rate of Return (IRR) of a project is the effective rate of return that makes the net present value of all cash flows from a particular investment equal to zero. It is the interest rate at which an investment breaks even; consequently it is often referred to as the Economic Rate of Return (ERR). It may be expressed mathematically as (Mireku-Gyimah, 2016):

IRR $=\mathrm{i}$ for $\Sigma \mathrm{PV}$ of Cash Inflows $@ \mathrm{i}^{*}=\Sigma \mathrm{PV}$ of Cash Outflows@i*,or

IRR=i for NPV@ $\mathrm{i}=0$

where: $\quad \mathrm{i}=$ the interest rate; and

$\mathrm{i}^{*}=$ the Minimum Rate of Return (MRR).

When the IRR $=i^{*}$, the project breaks even. When the IRR $<i^{*}$, the project is considered to be economically not viable. When IRR $>i^{*}$, the project is economically acceptable.

\subsubsection{Cash Flow Analysis}

Sepulved et al. (1984) define cash flow for a business entity as the difference between the total cash receipts (inflows) and the total cash 
disbursements (outflows) for a given period of time, typically one year. In this study, the cash flow analysis carried out is based on the cash flow model of Stermole (1984) and takes cognisance of the fact that AQL's proposed quarry is located in Ghana and therefore the following mineral investment laws of Ghana apply:

(i) Royalty: Any mineral project in Ghana must pay a royalty of $5 \%$ on the gross revenue to the Ghana Government.

(ii) Income Tax: An operating mine is required to pay income tax of $35 \%$.

(iii) Windfall Tax (WT): An operating mine is required to pay a windfall tax at the rate of $10 \%$. The WT is payable on the CarryForward Cash Balance (CFCB) which can be calculated as: $\mathrm{CFCB}=\mathrm{TI}-(\mathrm{IT}+\mathrm{CI}+$ $\mathrm{AI})+(\mathrm{I}+\mathrm{CA}+\mathrm{LF})$, where $\mathrm{TI}$ is the taxable income, IT is the income tax, $\mathrm{CI}$ is the capital invested, AI is the addition to inventory, I is the interest paid on capital, CA is the capital allowances, all in the year of assessment, and LF is the loss brought forward from the previous year. It is to be noted that the Windfall Tax is yet to be enforced but it is included here so as to avoid a fiscal shock if it is enforced.

(iv) Capital Allowance: An operating mine is entitled to a capital allowance which is a straight line depreciation of capital expenditure over 5 years (20\% per year).

(v) Investment allowance of 5\% in the $1^{\text {st }}$ year only.

(vi) Loss Carry-Forward: An operating mine is entitled to carrying forward the loss incurred in a particular year of assessment to the next year, except that the amount carried forward should not exceed the capital allowance (depreciation) in that year.

The cash flow analysis is also based on the following assumptions:

(i) Base case aggregate price is fixed at $\$$ $15.63 / \mathrm{m}^{3}$;

(ii) Price escalation during the period of assessment is not considered; (iii) The Minimum Rate of Return (MRR) is $15 \%$;

(iv) Capital and operating cost estimates are considered to be accurate within a variation of about $\pm 10 \%$;

(v) The mineral reserve estimate is considered to be fairly accurate but a $10 \%$ loss during quarrying must be observed;

(vi) The initial investment is made the year before the start of the project (i.e. year 0) and full production starts at year 1 ;

(vii) The capital structure is made up of $80 \%$ equity and $20 \%$ loan; and

(viii) There is no salvage value of plant and equipment at the end of the project.

\subsubsection{Sensitivity Analysis}

The essence of sensitivity analysis is to determine the effect of changes in a selected economic parameter on the economic viability of the project while all other economic parameters remain constant (Mireku-Gyimah, 2016). In this study, sensitivity analysis was conducted to investigate the effect of changes in capital cost, revenue or operating cost on the economic viability of the project. This was carried out by varying one of the economic parameters by $\pm 20 \%$ intervals up to $\pm 60 \%$ while keeping the other parameters constant and calculating the NPV and IRR consequent to the changes.

\subsubsection{Risk Analysis}

Spencer (1991) defines risk as the uncertainty associated with the financial outcome of a particular investment proposal. In this study, risk analysis was conducted to investigate the project's viability in a real world setting where the major economic (mineral project risk) factors such as the capital cost, operating cost, selling price, annual production, interest rate and tax can vary simultaneously but independently. This was conducted by varying the parameters simultaneously but independently up to $\pm 20 \%$.

Because of the difficulty in estimating country risk factors such as political, geographical, economic and social, which are intangible, a higher discount rate was selected as compensation. The methodology of the risk analysis is to:

(i) Construct a cumulative frequency distribution for each of the parameters; 
(ii) Use a simple Visual Basic program and Microsoft Excel Macro which utilises the Monte Carlo Simulation technique to simulate risk parameters like capital cost, operating cost, selling price, annual production, interest rate and tax. The programme was set to generate 500 iterations of the parameters. Randomly selected output of risk parameters were drawn and inserted into the cash flow model to compute the NPV and IRR values for each set of variables. This means 500 values of NPV and 500 values of IRR are generated. The cumulative distributions of the NPV values and those of the IRR values are then automatically constructed, from which the probabilities of success and failure of the project can be read.

\section{Results and Discussion}

From Equation (1), the Annual Gross Revenue (AGR) is calculated as:

$$
\begin{array}{rll}
\text { AGR } & =12 \text { MP } \times \text { WAP } \\
\text { where } & \text { MP } & =\text { Monthly Production } \\
& \text { WAP } & =\text { Weighted Average Price } \\
\therefore \quad \text { AGR } & =12\left(25000 \mathrm{~m}^{3}\right)\left(\$ 15.63 / \mathrm{m}^{3}\right) \\
& & =\$ 4689.00 \times 10^{3}
\end{array}
$$

Table 1 presents the details of the capital cost estimate. It can be seen that the total capital cost for the project is $\$ 3656.01 \times 10^{3}$. In accordance with the decision of the BoD of AQL, $80 \%$ of this capital cost constituting \$2 $924 \quad 808.80$ is considered to be equity while the remaining $20 \%$ constituting \$731202.20 is a loan.

Table 2 presents the details of the operating cost estimate. It can be seen that the Annual Operating Cost (AOW) is $\$ 1716.96 \times 10^{3}$. Based on this, Equation (2) is used to calculate the Working Capital (WC) as:

$$
\mathrm{WC}=\mathrm{AOW} \times\left(\frac{\mathrm{Y} \text { months }}{12 \text { months }}\right)
$$

$$
\begin{array}{lll}
\text { where } & \mathrm{Y} & =3 . \\
\therefore \quad & \text { WC } & =\$ 1716.96 \times 10^{3}\left(\frac{3}{12}\right) \\
& & =\$ 429240.00
\end{array}
$$

Since the proposed Monthly Production (MP) is 25 $000 \mathrm{~m}^{3}$, the total Granite Reserve (GR) is 6286 $208 \mathrm{~m}^{3}$ and the mining loss is $10 \%$, the Life (L) of the quarry can be calculated as:

$$
\mathrm{L}=\frac{6286208 \times 0.9}{12 \times 2500}=18.86
$$

Although the life of the quarry is 18.86 years, the economic analysis is restricted to 10 years because the BoD of AQL is specifically interested in the viability of the project over a 10 year period, after which the salvage value of all equipment and installation is considered to be zero.

The cash flow analysis over the 10 year period is carried out using the following estimated values as the base scenario:

$\begin{array}{lll}\text { Gross Annual Revenue } & = & \$ 4689000.00 \\ \text { Total Capital Cost } & = & \$ 3656011.00 \\ \text { Annual Operating Cost } & = & \$ 1716960.00 \\ \text { Annual Working Capital } & = & \$ 429240.00\end{array}$

The results of the cash flow analysis are summarised in Table 3. From the cash flow analysis, it can be observed that the AQL quarry project has a positive Net Present Value (NPV) of $\$$ 5171110.82 and Internal Rate of Return (IRR) of $53.01 \%$. Since the NPV $>0$ and the IRR $>$ MRR, it can be concluded that the quarry project is profitable. Also, the Pay Back Period (PBP) of the project is less than 3 years.

The results of the sensitivity analysis are presented in Figs. 2 and 3 for NPV and IRR respectively. The results show that:

(i) If all other economic parameters remain constant, the quarry project can withstand up to $40 \%$ drop in revenue and still be profitable;

(ii) If all other economic parameters remain constant, the quarry project is not very sensitive to capital cost; it can absorb over $60 \%$ increase in capital cost and still be profitable; and

(iii) The quarry project is also not very sensitive to operating cost; if all other economic parameters remain constant, it can absorb over $60 \%$ increase in operating cost and still be profitable.

A summary of the results of the risk analysis are presented as cumulative frequency distributions of NPV and IRR in Figs. 4 and 5 respectively. The risk profile indicates that the probability of failure, i.e. the probability that the NPV is less than or equal to zero (NPV $\leq 0$ ) is $1.8 \%$ and the probability that IRR is less than or equal to the MRR of $15 \%$ is also $1.8 \%$, which means the project's profitability of success is $98.2 \%$. 
Table 1 Details of Capital Cost Estimate

\begin{tabular}{|c|c|}
\hline Cost Centre & $\begin{array}{c}\text { Amount } \\
\left(\mathrm{USS} \times \mathbf{1 0}^{3}\right)\end{array}$ \\
\hline $\begin{array}{l}\text { CC1 Pre-production Cost } \\
\text { i. Exploration, Acquisition and Consultancy }\end{array}$ & 130.00 \\
\hline 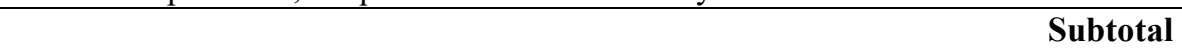 & 130.00 \\
\hline $\begin{aligned} & \text { CC2 Direct Capital Cost } \\
& \text { 1. } \text { Stripping, Drill and Blast } \\
& \text { i. } \text { CAT 330D Hydraulic Backhoe Excavator x } 1 \\
& \text { ii. } \text { Top-Hammer Atlas Copco Flexiroc T40 drill rig x } 1 \\
& \text { iii. } \text { 12.5 RAW Hydraulic Hammer x } 1\end{aligned}$ & $\begin{array}{r}190.00 \\
260.00 \\
8.58\end{array}$ \\
\hline Subtotal & 618.58 \\
\hline $\begin{aligned} \text { 2. } & \text { Loading and Hauling } \\
\text { i. } & \text { Volvo EC300DL Hydraulic Backhoe Excavator x } 2 \\
\text { ii. } & \text { China Sinotruk Howo } 371\left(18 \mathrm{~m}^{3}\right) \text { dump trucks x } 3 \\
\text { iii. } & \text { CAT } 12 \mathrm{M} 3 \text { motor grader x } 1\end{aligned}$ & $\begin{array}{l}330.00 \\
105.00 \\
210.00\end{array}$ \\
\hline e & 645.00 \\
\hline $\begin{array}{l}\text { 3. Crushing and Screening } \\
\text { Complete Shangai Zenith Crushing Plant comprising the following: } \\
\text { i. Vibrating Feeder x } 1 \\
\text { ii. Jaw Crusher x } 1 \\
\text { iii. Cone Crusher x } 1 \\
\text { iv. Two Vibrating Screen (type } 1) \times 2 \\
\text { v. Two Vibrating Screen (type } 2) \times 2 \\
\text { vi. Set of Belt Conveyors } \\
\text { Total Freight on Board ( FOB) value } \\
\text { vii. Freight, Insurance and Installation }(8.5 \% \text { of FOB) }\end{array}$ & $\begin{array}{r}20.96 \\
203.23 \\
229.52 \\
65.00 \\
45.16 \\
129.20 \\
692.56 \\
58.91\end{array}$ \\
\hline 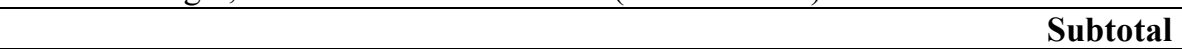 & 751.98 \\
\hline $\begin{aligned} \text { 4. } & \text { Re-handling } \\
\text { i. } & \text { One XCMG LW 800K wheel loader }\end{aligned}$ & 70.00 \\
\hline Subtotal & 70.00 \\
\hline $\begin{aligned} \text { 5. } & \text { Infrastructure and Site Works } \\
\text { i. } & \text { Site Development } \\
\text { ii. } & \text { Access Roads and Drainage } \\
\text { iii. } & \text { Administration and Sales Offices }\left(65 \mathrm{~m}^{2}\right) \times 2 \\
\text { iv. } & \text { Warehouse Building }\left(100 \mathrm{~m}^{2}\right) \times 2 \\
\text { v. } & \text { Workshop Building }\left(200 \mathrm{~m}^{2}\right) \times 1 \\
\text { vi. } & \text { Crushing Plant Watch Tower }\left(70 \mathrm{~m}^{2}\right) \times 2 \\
\text { vii. } & \text { Canteen Shed }\left(65 \mathrm{~m}^{2}\right) \times 1 \\
\text { viii. } & \text { Changing Room and Bathhouse }\left(45 \mathrm{~m}^{2}\right) \times 1 \\
\text { ix. } & 450 \text { KVA Cummins Electric Generator set x } 2 \\
\text { x. } & 65 \text { KVA OLYMPIAN GEP65-9 Electric Generator set x } 1 \\
\text { xi. } & \text { HMS CIRIS CRS 6-25 Submersible Pump x } 2 \\
\text { xii. } & \text { China Sinotruk Howo }\left(19.0 \mathrm{~m}^{3}\right) \text { Water Tanker and Sprinkler x } 1 \\
\text { xiii. } & \text { Nissan Navara Pickup Trucks x } 5\end{aligned}$ & $\begin{array}{r}30.00 \\
30.00 \\
28.60 \\
42.00 \\
42.00 \\
33.00 \\
13.65 \\
10.00 \\
70.00 \\
14.00 \\
2.60 \\
47.73 \\
150.00\end{array}$ \\
\hline Subtotal & 513.58 \\
\hline $\begin{array}{l}\text { CC3 Indirect Capital Cost } \\
\text { i. Permitting and Commissioning } \\
\text { ii. Compensation } \\
\text { iii. Resettlement } \\
\text { iv. Reclamation and Environment Protection }\end{array}$ & $\begin{array}{r}50.00 \\
100.00 \\
140.00 \\
160.00\end{array}$ \\
\hline Subtotal & 450.00 \\
\hline $\begin{array}{l}\text { CC4 Allowances } \\
\text { i. Contingency }(15 \%)\end{array}$ & 476.87 \\
\hline Total Capital Cost & 3656.01 \\
\hline
\end{tabular}


Table 2 Operating Cost Estimates for the New Quarry

\begin{tabular}{|c|c|c|c|}
\hline $\begin{array}{c}\text { Cost } \\
\text { Centre } \\
\end{array}$ & Classification & $\begin{array}{c}\mathrm{Cost} / \mathrm{m}^{3} \text { of } \\
\text { aggregate (USS) }\end{array}$ & $\begin{array}{c}\text { Annual Cost } \\
\left(\text { USS } \times 10^{3}\right)\end{array}$ \\
\hline OP1 & Stripping, Drill and Blast & & \\
\hline OP1.1 & Stripping & 0.20 & 60.00 \\
\hline OP1.2 & Drilling & 0.44 & 132.00 \\
\hline \multirow[t]{2}{*}{ OP1.3 } & Blasting & 1.70 & 510.00 \\
\hline & Subtotal & 2.34 & 702.00 \\
\hline \multirow[t]{2}{*}{ OP2 } & Mucking/Loading & 0.33 & 99.00 \\
\hline & Subtotal & $\mathbf{0 . 3 3}$ & 99.00 \\
\hline \multirow[t]{2}{*}{ OP3 } & Hauling & 0.06 & 18.00 \\
\hline & Subtotal & 0.06 & 18.00 \\
\hline \multirow[t]{2}{*}{ OP4 } & Road Maintenance & 0.10 & 30.00 \\
\hline & Subtotal & 0.10 & 30.00 \\
\hline OP5 & Crushing and Screening & & \\
\hline OP5.1 & Power Supply & 0.35 & 105.00 \\
\hline \multirow[t]{2}{*}{ OP5.2 } & Maintenance and Spare Parts & 0.33 & 99.00 \\
\hline & Subtotal & 0.68 & 204.00 \\
\hline \multirow[t]{2}{*}{ OP6 } & Re-handling and Loading & 0.14 & 42.00 \\
\hline & Subtotal & 0.14 & 42.00 \\
\hline OP7 & Supervision, Labour and Overheads & & \\
\hline OP7.1 & Supervision and Labour & 1.22 & 366.00 \\
\hline OP7.2 & Utilities & 0.13 & 39.00 \\
\hline OP7.3 & Office Supplies & 0.03 & 9.00 \\
\hline \multirow[t]{2}{*}{ OP7.4 } & Vehicles & 0.08 & 24.00 \\
\hline & Subtotal & 1.46 & 426.00 \\
\hline \multicolumn{4}{|c|}{ Allowance } \\
\hline & Contingency $(12 \%)$ & 0.61 & 183.96 \\
\hline & Total Annual Operating Cost (AOW) & 5.72 & 1716.96 \\
\hline
\end{tabular}




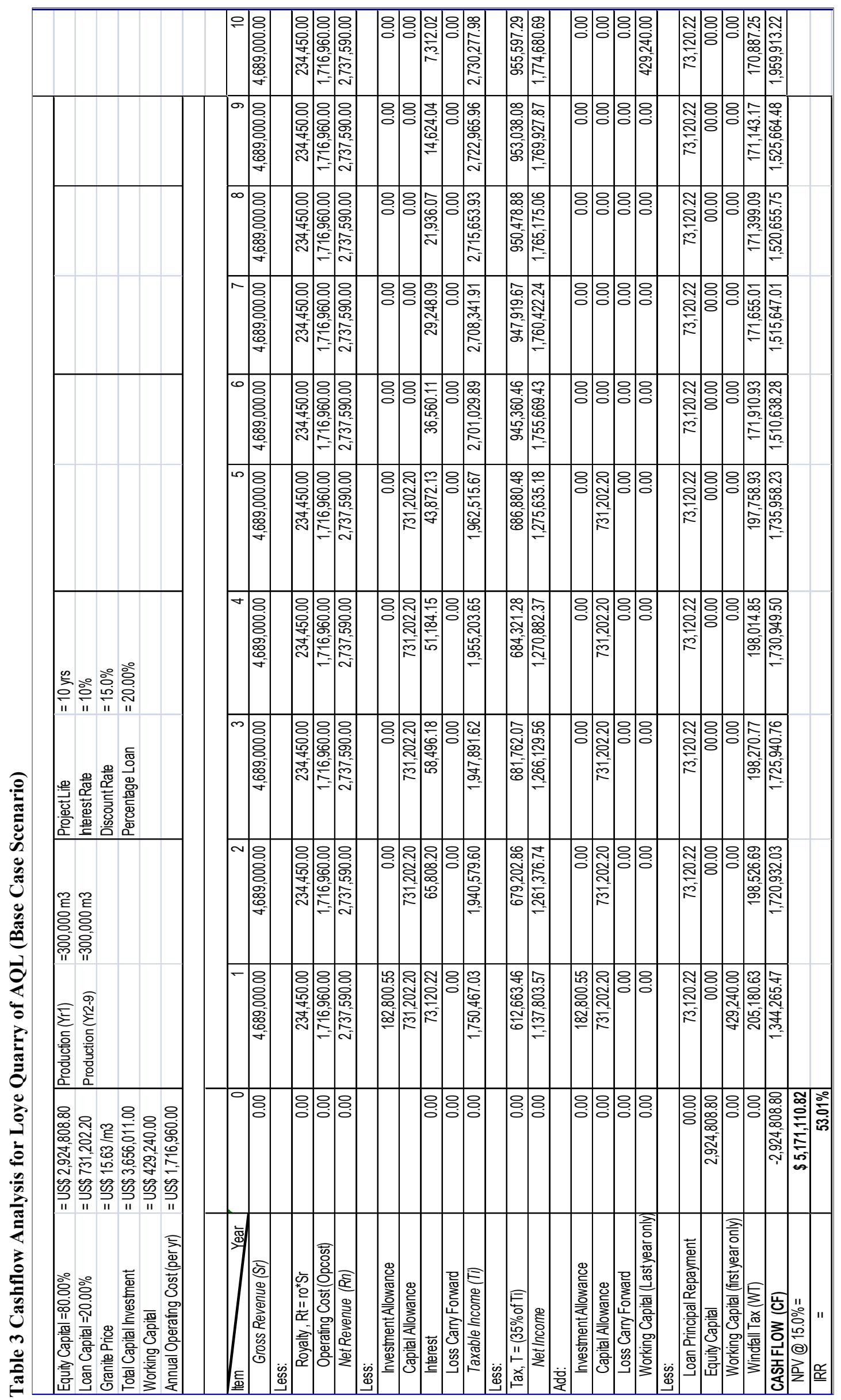




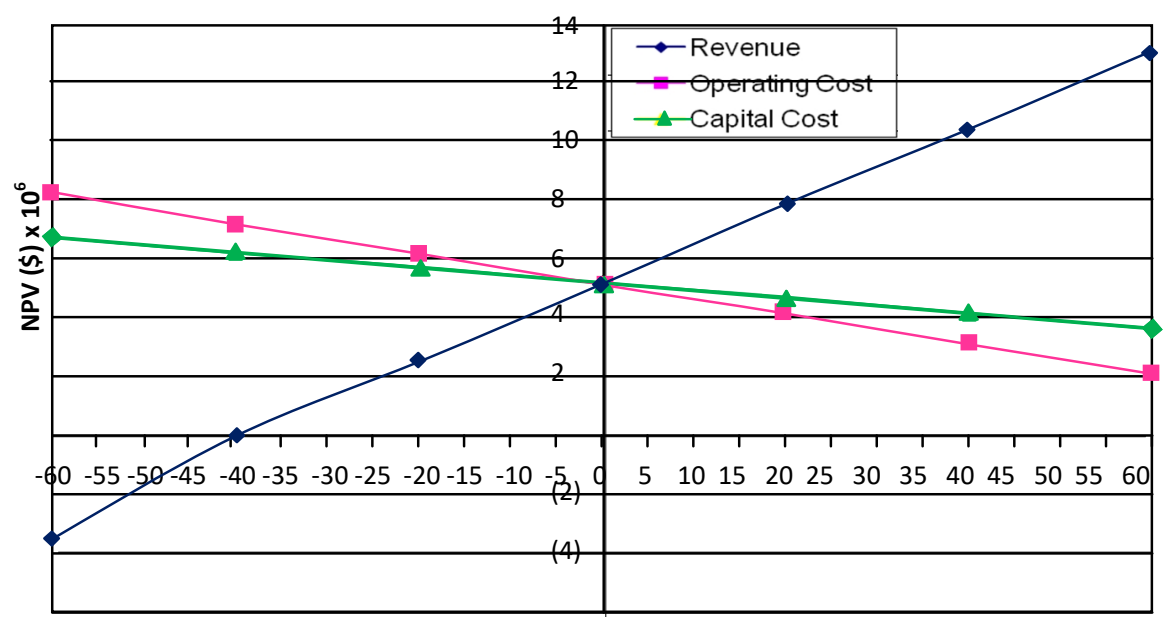

Variations in Investment Parameters (\%)

Fig. 2 NPV against Variation in Investment Parameters for AQL

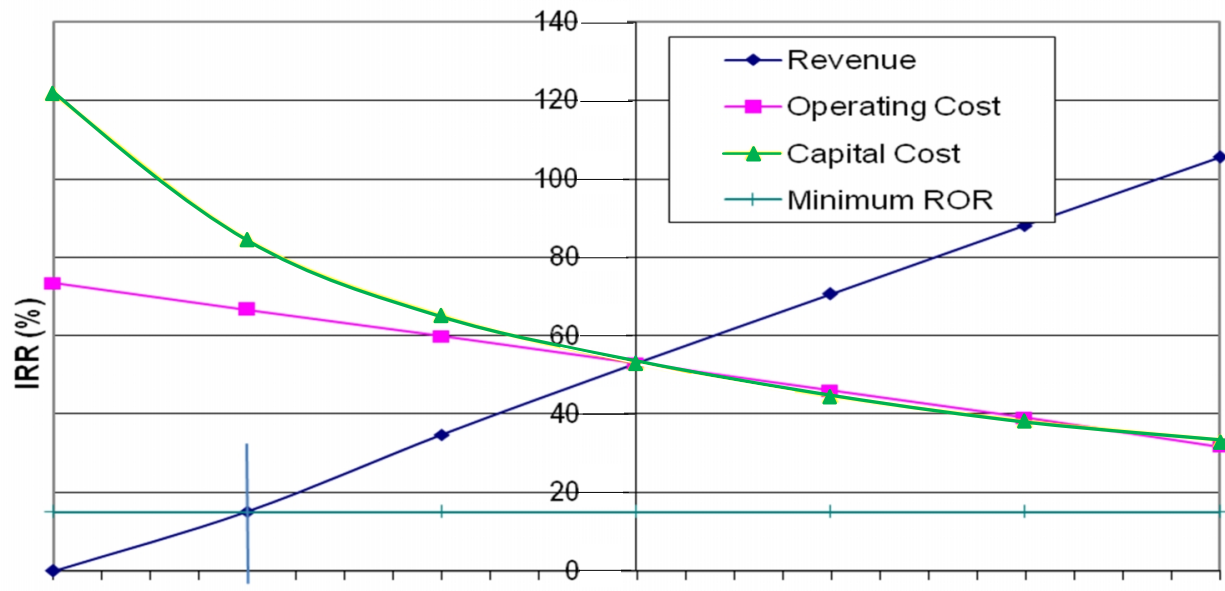

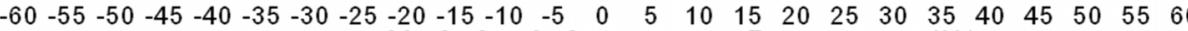
Variation in Investment Parameters (\%)

Fig. 3 IRR against Variation in Investment Parameters for AQL

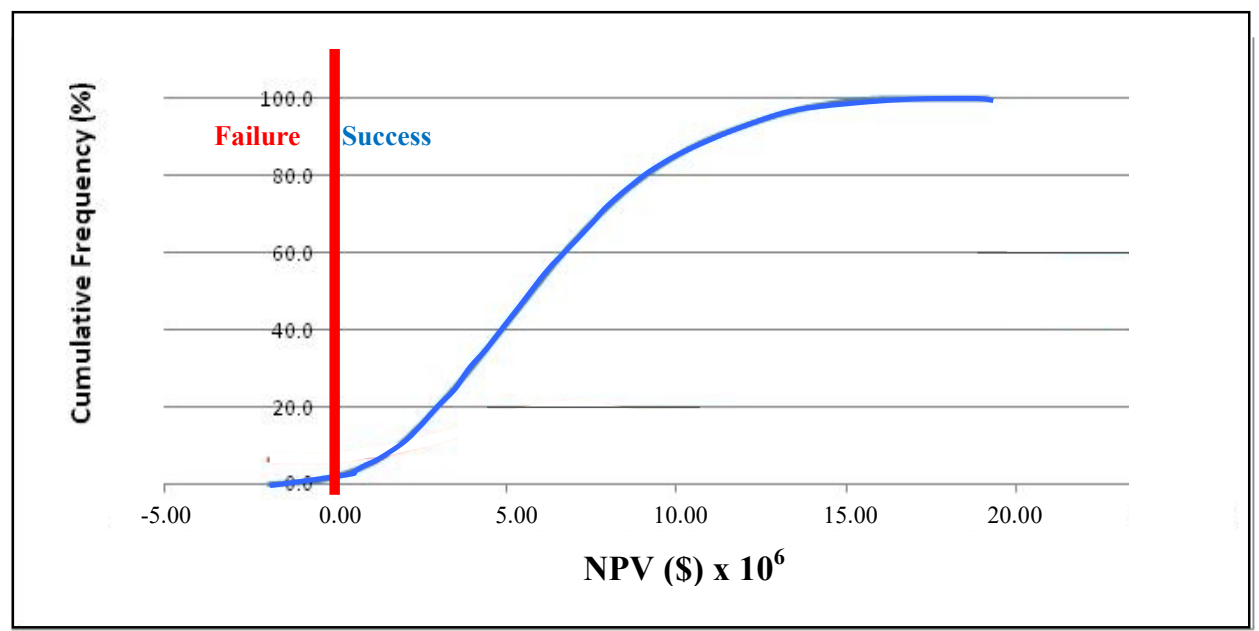

Fig. 4 Cumulative Frequency Distribution of NPV 


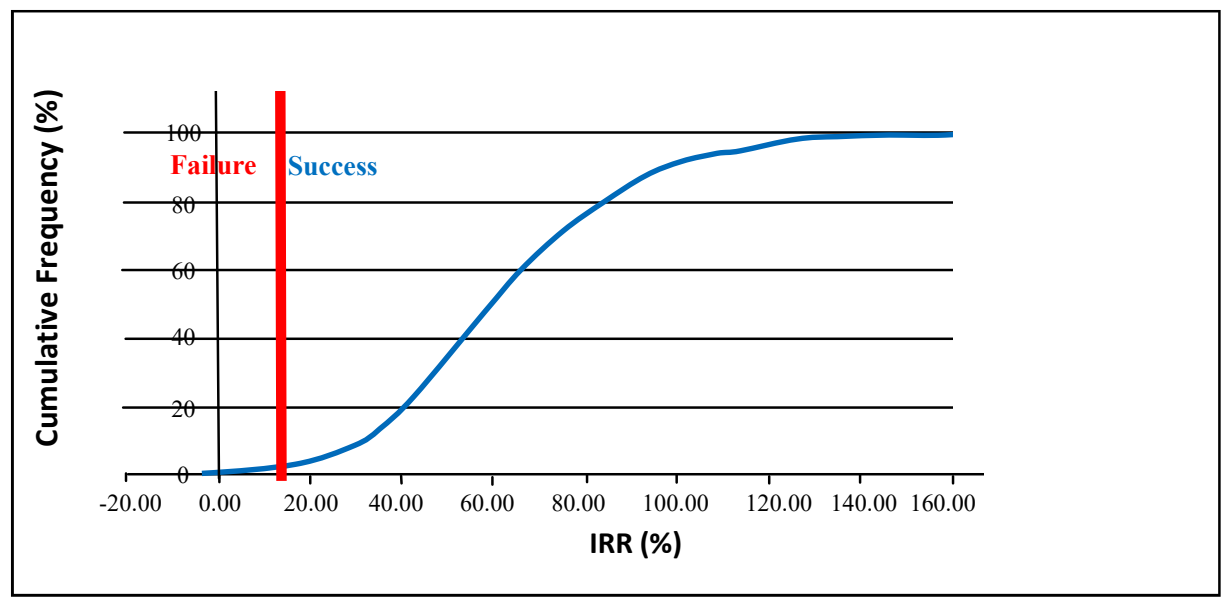

Fig. 5 Cumulative Frequency Distribution of IRR

\section{Conclusions and Recommendation}

\subsection{Conclusions}

After evaluating proposed new quarry project at the Loye Concession of AQL, the following conclusions are drawn:

(i) The proposed new quarry project would need a capital expenditure of \$ 3656011.00 to setup, a working capital of \$ 429240.00 and an annual operating cost of $\$ 1716$ 960.00 , in order to generate an estimated annual revenue of $\$ 4689000.00$.

(ii) Based on AQL's preferred capital structure of $80 \%$ equity and $20 \%$ loan, the NPV is $\$ 5$ 171110.82 and the IRR is $53.01 \%$, which show that the new quarry project is profitable, with a payback period of three years.

(iii) The project can withstand up to $40 \%$ drop in revenue, or over $60 \%$ increase in capital or $60 \%$ increase in operating cost, and still be profitable.

(iv) Should economic parameters like capital cost, operating cost, selling price and annual production vary simultaneously but independently up to $\pm 20 \%$, the project has $98.2 \%$ chance of being profitable.

\subsection{Recommendation}

It is recommended that the BoD of AQL invests in the new quarry at the Loye concession as it is economically viable with a probability of success of $98.2 \%$ and payback period less than three years.

\section{References}

Anon. (2006), Ghana Minerals and Mining Act, Act 703, Ghana Publishing Corporation (Printing Division), Accra, Ghana, pp. 1-59.

Anon. (2013), "The Composite Budget of the Awutu Senya East Municipal Assembly for the 2013 Fiscal Year", www.mofep.gov.gh, Accessed: January 15, 2014.

Anon. (2015), Income Tax Act, Act 896, Ghana Publishing Corporation (Printing Division), Accra, Ghana, $182 \mathrm{pp}$.

Gentry, D. W. and O'Neil, T. J. (1984), Mine Investment Analysis, Society of Mining Engineers, New York, pp. 1- 396.

Kesse, G. O. (1985), The Mineral and Rock Resources of Ghana, A. A. Balkema Publishers, Rotterdam, $610 \mathrm{pp}$.

Mireku-Gyimah, D. (2016), "Mine Economic and Financial Evaluation", MSc. Lecture Notes, University of Mines and Technology, Tarkwa, Ghana, pp. L1 p. 2 - L8 p. 23.

Scholleová, H., Svecovà, L., and Fotr, J. (2010), "Criteria for the Evaluation and Selection of Capital Projects", Journal of Intellectual Economics, No.1 (7), pp. 48 - 54.

Sepulved, J. A., Souder, W. E., and Gottfried, B. S. (1984), Theory and Problems of Engineering Economics, Schaum's Outline Series in Engineering, McGraw-Hill, pp. 18 - 183.

Spencer, R. (1991), "Mineral Evaluation", Short Course, Imperial College, University of London, pp. 119 - 125.

Stermole, F. J. (1984), Economic Evaluation and Investment Decision Methods, Investment Evaluations Corporation, Golden, Colorado, $10^{\text {th }}$ Edition, pp. $10-451$. 


\section{Authors}

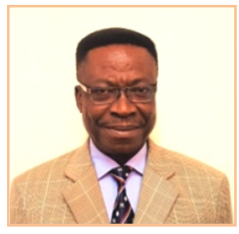

D. Mireku-Gyimah is a Professor of Mining Engineering and a Consulting Engineer currently working at the University of Mines and Technology, Tarkwa, Ghana. He holds the degrees of MSc from the Moscow Mining Institute, Moscow, Russia, and $\mathrm{PhD}$ and $\mathrm{DIC}$ from the Imperial College of Science, Technology and Medicine, London, UK. He is a member of Institute of Materials, Minerals and Mining of UK and New York Academy of Sciences and also a fellow of Ghana Institution of Engineers and the Ghana Academy of Arts and Science. His research and consultancy works cover Mine Design and Planning, Mine Feasibility Study, Operations Research, Environmental Protection and Corporate Social Responsibility Management.

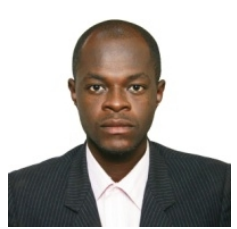

Nana Kwame Owusu Ansah is a Chartered Engineer and member of the Ghana Institution of Engineers. He is a Director at Tristern Consult Limited, an engineering consulting firm. He holds a

BSc degree in Civil Engineering from Kwame Nkrumah University of Science and Technology (KNUST), Kumasi and an MSc degree in Mining Engineering from University of Mines and Technology (UMaT), Tarkwa. His research interest includes the Application of Economic Decision Criteria in the Selection of Mineral and Infrastructure Projects and in Optimising Building and Bridge Structural Systems. 